\title{
New Strategic Thinking in Mitigating the Challenges in Implementing Key Performance Indicators (KPIs) and Increasing Efficiency in Corporate Performance Management in MENA Region
}

\author{
Moetaz Soubjaki ${ }^{1} \&$ Radwan Choughri ${ }^{1}$ \\ ${ }^{1}$ Management Department, School of Business, Jinan University, Tripoli, Lebanon \\ Correspondence: Moetaz Soubjaki, Management Department, School of Business, Jinan University, Tripoli, \\ Lebanon.
}

Received: July 6, 2019

Accepted: August 4, 2019

Online Published: August 6, 2019

doi:10.5430/jms.v10n4p59

URL: https://doi.org/10.5430/jms.v10n4p59

\begin{abstract}
The implementation of key performance indicators (KPIs) is a challenging task for many businesses. Yet, effective implementation of KPIs is among the major determinants of performance and success of an organization. This study explored the new strategic thinking in mitigating the challenges in implementing key performance indicators (KPIs) and increasing efficiency in corporate performance management in the Middle East \& North Africa (MENA) region. The study sought to test three hypotheses: (i) there is a significant relationship between having enough training and awareness sessions before implementation and effective implementation of KPIs; (ii) there is a significant relationship between having KPI professionals and specialists and effective implementation of KPIs; and (iii) there is a significant relationship between having clear KPI goals and objectives, on one hand, and the effective implementation of KPIs on the other. Hypotheses 2 and 3 were proved to be true while results for hypothesis 1 were inconclusive. A total of 1007 participants from across the MENA region were involved in the study. The findings demonstrate the importance of having clear KPI goals and objectives and KPI professionals or specialists to oversee the KPI selection and implementation process. Further research should be conducted to establish whether there is a significant relationship between having enough training and awareness sessions before implementation and effective implementation of KPIs.
\end{abstract}

Keywords: key performance indicators (KPIs), MENA region, organizational performance, KPI specialists

\section{Introduction}

Effective and accurate evaluation of performance and governance are crucial to the success of an organization. Evaluation of these aspects is usually achieved through the use of KPI systems. Key performance indicators (KPIs) refer to "quantifiable numeric or scale-based measurements that assess a company's effectiveness or success in reaching strategic and operational goals" (Coronel \& Morris, 2018, p. 595). KPIs are a good indicator of an organization's performances, improvements, and how well changes or new policies are being implemented in the organization. According to Cetinkaya et al. (2011), KPI systems comprise groups of interrelated KPIs, which can be used by an organization to implement strategic objectives into the operations of the organization. Usually, the determination of KPIs follows the determination of the strategic, operational, and tactical goals of the business (Coronel \& Morris, 2018).

KPIs have been studied widely in research (Marr, 2015; Sabri, 2019). The past studies have focused on diverse subjects including ways of KPIs implementation, the challenges in implementing KPIs (Sabri, 2019), and the impact of technology on the implementation of KPIs (Marr, 2015). However, the new ways of mitigating the challenges experienced during the implementation of KPIs is a subject that is underexplored, particularly in the Middle East and North Africa (MENA) region. This study seeks to fill this gap by investigating the new strategic thinking in mitigating the challenges in implementing key performance indicators (KPIs) and increasing efficiency in corporate performance management in MENA region. This study is necessary for two main reasons. First, research has shown that poor implementation of KPIs is among the main causes of inefficiency, particularly for construction firms in the MENA region (Khanzadi, Sheikhkhoshkar, \& Banihashemi, 2018). Second, few managers purpose to review the implementation of KPIs in their organization as a potential cause of poor corporate performance and inefficiency. 
Indeed, many managers tend to pay attention to other factors traditionally perceived as 'more significant' than KPI implementation, such as employee motivation, employee turnover rate, and employee skills and experience. Failure to hand KPI implementation sufficient respect relative to most traditional influencers of corporate performance is also one of the flaws in many of the past studies in this area (Leon, 2017). This is despite some past studies showing that effective implementation of KPIs can reduce operational errors (Rastock, 2017), average time and cost of diagnosing problems (Shohet \& Nobili, 2016), and improve compliance with industry regulations and policies (Rastock, 2017), thereby enhancing the overall performance of the business (Parmenter, 2015; Shohet \& Nobili, 2016).

Thus, this study seeks to emphasize the importance of effective implementation of KPIs in the attainment of high corporate performance and efficiency in an organization. Among the objectives of the paper is to draw conclusions and make recommendations that can assist business managers in the MENA region to enhance the implementation of KPIs in their organization, which would result in better corporate performance and efficiency.

\section{Literature Review}

The implementation of KPIs has its fair share of challenges. One of the challenges that managers tend to experience is how to break down the strategic objectives of a business into the relevant KPIs and determine the right period for reporting the KPIs (Cetinkaya et al., 2011). Managers have to be keen to ensure they only select the KPIs that assess and control the relevant processes of operations at the organization. It is also important to take into consideration all the potential trade-offs as some operational objectives might be complementary while others might be in conflict (Cetinkaya et al., 2011). Another challenge is ensuring that new or emerging operational goals, such as environmental, governance, and social goals, are integrated into the existing KPI system (Marr, 2015). Another key challenge in the implementation of KPIs for businesses in MENA region is finding ways to quantify some measures financially. For example, many environmental, governance, and social aspects are, according to Marr, hard to measure owing to difficulties in quantifying them financially.

Other challenges identified in past research include; wide variety of choices that make it difficult to identify the right KPIs that will yield the most for the least investment of resources and the continued reliance on traditional metrics that are increasingly losing relevance in the modern lean and dynamic business environments (Sabri, 2019). Sabri recommends several ways of mitigating the challenges experienced while implementing KPIs. These ways include; having trained KPI professionals to oversee the KPIs implementation process and having clear KPI goals and objectives.

Other methods of mitigation proposed in past studies include spreading awareness through training prior to the implementation of the KPIs (Parmenter, 2015) and combining the traditional business KPIs with modern data-sets, such as customer relationship management or employee performance management databases (Marr, 2015). According to Marr, unlike in the past when data was stored mainly in physical form in files and cabinets, advances in technology means that all the data about an organization can be stored in a single computer or a single computer disk. This means that many businesses no longer have to experience the challenge of requiring to have large budgets to organize, store, and manage huge data sets. Indeed, modern businesses are characterized by the presence of large amounts of data stored within business computers and online platforms and databases, such as social media and cloud storages. The new challenge is in securing the data stored in computers or the cloud from illegal access by hackers and people with malicious intentions. Departmentalization has been suggested as one of the solutions that can make it easier to handle the diverse data on KPIs (Marr, 2015). Departmentalization means that this data could be spread out across many areas and databases and are likely to be held in different formats. A potential consequence of this diversity in storage formats is the fact that some data, such as programming data, may not be understandable to people lacking programming skills.

Another challenge experienced by business in the MENA region during the implementation of KPIs is ensuring all the local content requirements are met. Most of the countries in the MENA region have unique local content requirements (LCRs). According to Olawuyi (2017), MENA countries including the United Arab Emirates, Qatar, Kuwait, Saudi Arabia, Iraq, and Bahrain are increasingly introducing LCRs into their laws via regulations, legislation, guidelines, and bidding practices. Many of these countries have LCRs with fixed KPIs that require businesses to provide updates at least twice a year on the level and scope of compliance with LCRs (Olawuyi, 2017). Additionally, in some of the MENA countries, such as Iraq, researchers have reported a serious gap in the identification of business information modeling capabilities in KPIs of business projects, such as construction projects (Khanzadi, Sheikhkhoshkar, \& Banihashemi, 2018).

Another area where businesses in the MENA region have experienced challenges while implementing KPIs is in 
evaluating performance in projects where services have been outsourced. This is because, as Akkermans et al. (2019) argue, the quality of performance in projects where services have been outsourced is dependent on both the behavior and efforts of the supplier and buyer. This means that focusing KPIs on either the supplier or the buyer is unlikely to produce accurate results. Akkermans et al. recommend the application of collaborative KPIs, which would evaluate and reward the behaviors of both the supplier and the buyer of the contracted services. Collaborative KPIs assess the performance of the supplier as well as the contribution of the buyer in facilitating the contribution of the supplier.

Finally, determination of the right or relevant KPIs is also among the greatest challenges faced by businesses when planning and implementing KPI systems (Stricker, Minguillon, \& Lanza, 2017). Stricker et al. propose the use of a linear program to select KPIs as a way of ensuring the selected KPIs are the right number and possess just the right level of information content.

From the findings in the literature review, the following hypotheses are proposed:

Null Hypothesis $\left(\mathrm{H}_{1}\right)$ : There is no significant relationship between having enough training and awareness sessions before implementation and effective implementation of KPIs.

Alternative Hypothesis $\left(\mathrm{H}_{\mathrm{a}}\right)$ : There is a significant relationship between having enough training and awareness sessions before implementation and effective implementation of KPIs.

Null Hypothesis $\left(\mathrm{H} 2_{0}\right)$ : There is no significant relationship between having KPI professionals and specialists and effective implementation of KPIs

Alternative Hypothesis $\left(\mathrm{H}_{2}\right.$ ): There is a significant relationship between having KPI professionals and specialists and effective implementation of KPIs

Null Hypothesis $\left(\mathrm{H}_{0}\right)$ : There is no significant relationship between having clear KPI goals and objectives, on one hand, and the effective implementation of KPIs on the other.

Alternative Hypothesis $\left(\mathrm{H}_{\mathrm{a}}\right)$ : There is a significant relationship between having clear KPI goals and objectives, on one hand, and the effective implementation of KPIs on the other.

\section{Research Methodology}

This study sought to identify and understand new strategic thinking in mitigating the challenges in implementing key performance indicators (KPIs) and increasing efficiency in corporate performance management in MENA region. Thus, the study is descriptive in nature and a descriptive research design was used. The main goal of a descriptive research design is to explain or describe phenomena (Brockopp et al., 2018). This design provides insights relating to associations between phenomena (Heppner et al., 2015). Quantitative data was collected to allow for statistical analyses and generalization of findings to populations beyond the sample studied (Brockopp et al., 2018).

The study targeted respondents with roles of either managers or directors in businesses within the MENA region. Over 2,000 invites for participation in the study were sent out and 1007 valid responses were received. The requirement that only managers or directors could participate in the study meant that the study sample had to be purposively sampled. Data from the respondents was obtained via structured questionnaires. People in the study sample were sent an email inviting them to participate in an online questionnaire that was hosted on KwikSurveys.com. The purpose of the study, the privacy and confidentiality policies, and the manner in which the collected fata would be used were all explained in the emails to the respondents.

The questionnaire had been subjected to a pilot study to test it for relevance and understandability. The online link to the questionnaire was left active for two months to give as many participants as possible the opportunity to complete the survey. The collected data was downloaded and subjected to statistical analysis via the Statistical Package for the Social Sciences (SPSS) software. The results of this analysis are shown in the next section.

\section{Results}

Over 2,000 managers and/or directors were invited to participate in this study. A total of 1007 valid responses were received, representing a response rate of 50.35 percent. The demographics for the respondents are summarized in the tables below. 


\subsection{Demographics}

Table 1. Gender

\begin{tabular}{llllll}
\hline Value Label & Value & Frequency & Percent & Valid Percent & Cum Percent \\
\hline Gender & Female & 232 & 23 & 23 & 23 \\
\cline { 2 - 6 } & Male & 775 & 77 & 77 & 100 \\
\hline Total & & 1007 & 100.0 & 100.0 & \\
\hline
\end{tabular}

Male respondents comprised 77 percent of the total respondents with women completing the remaining 23 percent. A majority of the respondents (66 percent) had an undergraduate degree, 23 percent had a master's degree, and 11 percent had a doctorate degree. The study targeted managers and directors as shown in Table 3 . The representation or distribution of respondents across the MENA countries is shown in Table 4.

Table 2, Level of education

\begin{tabular}{|c|c|c|c|c|c|}
\hline Value Label & Value & Frequency & Percent & Valid Percent & Cum Percent \\
\hline \multirow{3}{*}{$\begin{array}{l}\text { Level } \\
\text { Education }\end{array}$} & $\mathrm{BA}$ & 664 & 66 & 66 & 66 \\
\hline & MBA & 232 & 23 & 23 & 89 \\
\hline & $\mathrm{PhD}$ & 111 & 11 & 11 & 100 \\
\hline Total & & 1007 & 100.0 & 100.0 & \\
\hline
\end{tabular}

Table 3. Job title

\begin{tabular}{|c|c|c|c|c|c|}
\hline Value Label & Value & Frequency & Percent & Valid Percent & Cum Percent \\
\hline \multirow[t]{8}{*}{ Job Title } & HR Manager/ Director & 212 & 21 & 21 & 21 \\
\hline & $\begin{array}{lll}\text { Strategy }- & \text { Performance } \\
\text { Manager/Director } & \end{array}$ & 302 & 30 & 30 & 51 \\
\hline & Sales Manager/ Director & 111 & 11 & 11 & 62 \\
\hline & Finance Manager/Director & 141 & 14 & 14 & 76 \\
\hline & Managing Director/ CEO & 91 & 9 & 9 & 85 \\
\hline & Training Manager/ Director & 60 & 6 & 6 & 91 \\
\hline & IT Manager/ Director & 60 & 6 & 6 & 97 \\
\hline & Audit - Risk Manager/ Director & 30 & 3 & 3 & 100 \\
\hline Total & & 1007 & 100.0 & 100.0 & \\
\hline
\end{tabular}

Table 4. Country

\begin{tabular}{llllll}
\hline Value Label & Value & Frequency & Percent & Valid Percent & Cum Percent \\
\hline Country & Kingdom of Saudi Arabia & 191 & 19 & 19 & 19 \\
\cline { 2 - 6 } & United Arab Emirates & 171 & 17 & 17 & 36 \\
\cline { 2 - 6 } & Lebanon & 40 & 4 & 4 & 40 \\
\cline { 2 - 5 } & Jordan & 40 & 4 & 4 & 44 \\
\cline { 2 - 5 } & Egypt & 111 & 11 & 11 & 65 \\
\cline { 2 - 5 } & Tunisia & 91 & 9 & 9 & 64 \\
\hline
\end{tabular}




\begin{tabular}{llllll}
\hline & Qatar & 91 & 9 & 9 & 73 \\
\cline { 2 - 6 } & Morocco & 60 & 6 & 6 & 79 \\
\cline { 2 - 6 } & Algeria & 30 & 3 & 3 & 82 \\
\cline { 2 - 6 } & Oman & 121 & 12 & 12 & 94 \\
\cline { 2 - 6 } & Kuwait & 61 & 6 & 6 & 100 \\
\hline Total & 1007 & 100.0 & 100.0 & \\
\hline
\end{tabular}

\subsection{Levels of KPI Implementation}

On the question of the levels of KPI implementation in the organization, individual KPIs were the most implemented at 42 percent, followed by departmental and organizational KPIs at 18 percent and 17 percent respectively as shown in Table 6.

Table 5. Industries

\begin{tabular}{|c|c|c|c|c|c|}
\hline Value Label & Value & Frequency & Percent & Valid Percent & Cum Percent \\
\hline \multirow[t]{11}{*}{ Industries } & Real Estate & 101 & 10 & 10 & 10 \\
\hline & Healthcare & 101 & 10 & 10 & 20 \\
\hline & Wholesale/ Trading & 201 & 20 & 20 & 40 \\
\hline & Education and Training & 81 & 8 & 8 & 48 \\
\hline & Consultancy & 70 & 7 & 7 & 55 \\
\hline & Insurance & 91 & 9 & 9 & 64 \\
\hline & Retail & 111 & 11 & 11 & 75 \\
\hline & Banking & 101 & 10 & 10 & 85 \\
\hline & Automotive & 70 & 7 & 7 & 92 \\
\hline & Hospitality & 60 & 6 & 6 & 98 \\
\hline & Manufacturing & 20 & 2 & 2 & 100 \\
\hline Total & & 1007 & 100.0 & 100.0 & \\
\hline
\end{tabular}

Table 6. What are the levels of KPI implementation in your organization?

\begin{tabular}{lllll}
\hline Value & Frequency & Percent & Valid Percent & Cum Percent \\
\hline Organizational & 171 & 17 & 17 & 17 \\
\hline Departmental & 181 & 18 & 18 & 35 \\
\hline Individual & 423 & 42 & 42 & 77 \\
\hline All & 232 & 23 & 23 & 100 \\
\hline Total & 1007 & 100.0 & 100.0 & \\
\hline
\end{tabular}

Table 7. Most employees resist applying KPIs, what are the most reasons for resistance to KPI Implementation

\begin{tabular}{lllll}
\hline Value & Frequency & Percent & Valid Percent & Cum Percent \\
\hline Exposed/ Uncovered & 232 & 23 & 23 & 23 \\
\hline Reduce freedom of action & 61 & 6 & 6 & 29 \\
\hline Too instrumental & 10 & 1 & 1 & 30 \\
\hline
\end{tabular}




\begin{tabular}{lllll}
\hline Formal approach & 10 & 1 & 1 & 31 \\
\hline Discussion is time consuming & 10 & 1 & 1 & 32 \\
\hline Fear of change & 171 & 17 & 17 & 49 \\
\hline Extra job/ responsibility & 181 & 18 & 18 & 67 \\
\hline $\begin{array}{l}\text { Lack of trust in the system } \\
\text { benefits on a personal level }\end{array}$ & 332 & 33 & 33 & 100 \\
\hline Total & 1007 & 100 & 100 & \\
\hline
\end{tabular}

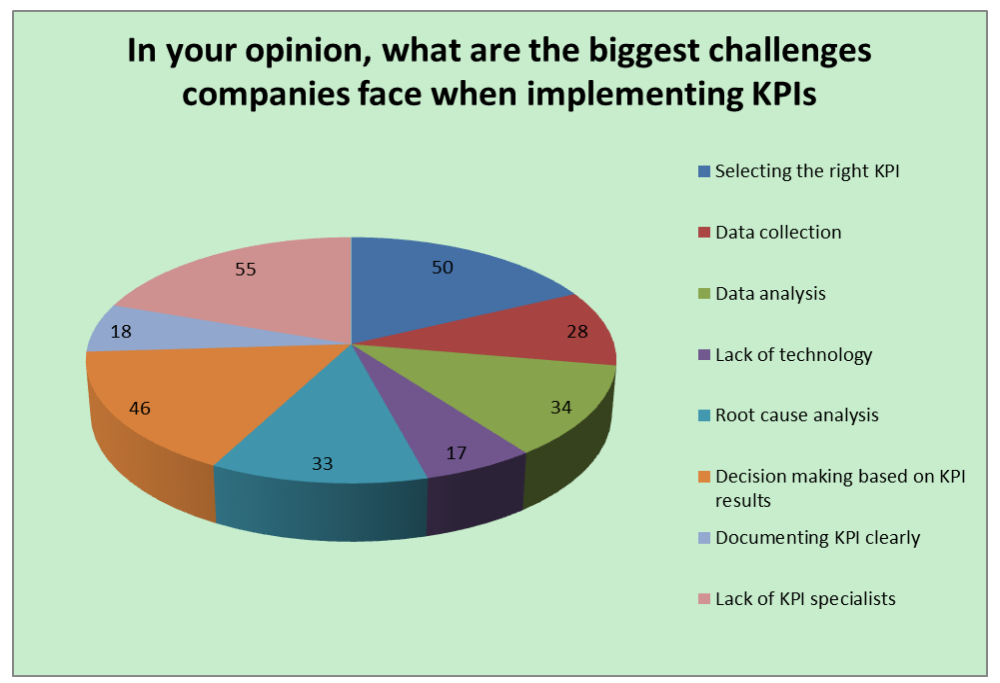

Figure 1. In your opinion, what is the biggest challenges companies face when implementing KPIs

A majority of the respondents (55 percent) felt that "lack of KPI specialists" was the biggest challenge faced by the organization during the implementation of KPIs. The next biggest challenge was "selecting the right KPI" (50 percent) while the least was "lack of technology" as shown in Figure 1. These findings are consistent with previous research results in the area, which have cited root cause analysis (RCA) (Latino, Latino, Latino, 2016), selecting the right KPI (Cetinkaya et al., 2011), lack of KPI specialists (Marr, 2015), and decision making based on KPI results (Sabri, 2019) as some of the common challenges that complicate the implementation of KPIs. All the respondents in this study felt that it was 'important' (30 percent) or 'very important' ( 70 percent) to have decision-making that is based on KPIs after root cause analysis. 28 percent and 54 percent of the respondents felt that it was 'important' and 'very important' respectively to review KPIs on a quarterly basis. Thus, despite the need to implement KPIs and mitigate the challenges that might hinder that implementation, it is clear from the responses in this study that majority of the respondents do not favor very frequent review of KPIs. Only 20 percent and 10 percent of the respondents felt that it was 'important' or 'very important' respectively to review KPIs on a weekly basis. Nevertheless, most of the respondents did not favor a review of KPIs on an annual basis.

Table 8. Using the Key Performance Indicators (KPIs) Development scale below, please indicate how important each of these factors is for your organization

\begin{tabular}{lllll}
\hline & $\begin{array}{l}\text { Not } \\
\text { Important (1) }\end{array}$ & $\begin{array}{l}\text { Slightly } \\
\text { Important (2) }\end{array}$ & $\begin{array}{l}\text { Important } \\
(3)\end{array}$ & $\begin{array}{l}\text { Very } \\
\text { Important (4) }\end{array}$ \\
\hline Having a clear KPIs for goals and objectives & $5 \%$ & $5 \%$ & $10 \%$ & $80 \%$ \\
\hline Having a well-designed KPIs selection process & $15 \%$ & $20 \%$ & $30 \%$ & $35 \%$ \\
\hline Having a KPI target benchmark & $4 \%$ & $17 \%$ & $25 \%$ & $54 \%$ \\
\hline
\end{tabular}




\begin{tabular}{lllll}
\hline Having a KPI testing before approval & $23 \%$ & $13 \%$ & $44 \%$ & $20 \%$ \\
\hline Having clear KPIs documentation & $35 \%$ & $5 \%$ & $27 \%$ & $33 \%$ \\
\hline $\begin{array}{l}\text { Having a clear data gathering process for KPIs } \\
\text { calculation }\end{array}$ & $5 \%$ & $9 \%$ & $31 \%$ & $55 \%$ \\
\hline $\begin{array}{l}\text { Having decision making based on KPIs after } \\
\text { root cause analysis }\end{array}$ & $0 \%$ & $0 \%$ & $30 \%$ & $70 \%$ \\
\hline Review KPIs on a weekly basis & $30 \%$ & $40 \%$ & $20 \%$ & $10 \%$ \\
\hline Review KPIs on a monthly basis & $3 \%$ & $13 \%$ & $50 \%$ & $34 \%$ \\
\hline Review KPIs on a quarterly basis & $7 \%$ & $11 \%$ & $28 \%$ & $54 \%$ \\
\hline Review KPIs on a yearly basis & $70 \%$ & $13 \%$ & $7 \%$ & $10 \%$ \\
\hline $\begin{array}{l}\text { Having KPI professionals and specialists } \\
\text { Having change programs with KPI }\end{array}$ & $0 \%$ & $8 \%$ & $66 \%$ & $26 \%$ \\
$\begin{array}{l}\text { implementation } \\
\text { Having technology to support KPI } \\
\text { implementation }\end{array}$ & $23 \%$ & $21 \%$ & $24 \%$ & $38 \%$ \\
\hline $\begin{array}{l}\text { Having a clear KPI implementation internal } \\
\text { communication plan }\end{array}$ & $6 \%$ & $16 \%$ & $19 \%$ & $25 \%$ \\
\hline $\begin{array}{l}\text { Having enough training and awareness } \\
\text { sessions before implementation }\end{array}$ & $15 \%$ & $7 \%$ & $37 \%$ & $41 \%$ \\
\hline
\end{tabular}

Table 9. How would you rate your organization's actual performance on the following factors?

\begin{tabular}{lllll}
\hline & $\begin{array}{l}\text { Unsatisfactory } \\
(1)\end{array}$ & $\begin{array}{l}\text { Improvement } \\
\text { Needed (2) }\end{array}$ & $\begin{array}{l}\text { Meets } \\
\text { Expectations (3) }\end{array}$ & $\begin{array}{l}\text { Exceeds } \\
\text { Expectations (4) }\end{array}$ \\
\hline $\begin{array}{l}\text { Having a clear KPIs for goals and } \\
\text { objectives }\end{array}$ & $13 \%$ & $43 \%$ & $21 \%$ & $23 \%$ \\
\hline $\begin{array}{l}\text { Having a well-designed KPIs selection } \\
\text { process }\end{array}$ & $40 \%$ & $18 \%$ & $29 \%$ & $13 \%$ \\
\hline Having a KPI target benchmark & $43 \%$ & $21 \%$ & $13 \%$ & $23 \%$ \\
\hline Having a KPI testing before approval & $70 \%$ & $9 \%$ & $16 \%$ & $5 \%$ \\
\hline Having clear KPIs documentation & $45 \%$ & $16 \%$ & $20 \%$ & $19 \%$ \\
\hline $\begin{array}{l}\text { Having a clear data gathering process } \\
\text { for KPIs calculation }\end{array}$ & $20 \%$ & $37 \%$ & $35 \%$ & $8 \%$ \\
\hline $\begin{array}{l}\text { Having decision making based on KPIs } \\
\text { ffter root cause analysis }\end{array}$ & $10 \%$ & $54 \%$ & $14 \%$ & $22 \%$ \\
\hline Review KPIs on a weekly basis & $63 \%$ & $15 \%$ & $17 \%$ & $5 \%$ \\
\hline Review KPIs on a monthly basis & $15 \%$ & $37 \%$ & $33 \%$ & $28 \%$ \\
\hline Review KPIs on a quarterly basis & $23 \%$ & $19 \%$ & $30 \%$ & $30 \%$ \\
\hline $\begin{array}{l}\text { Review KPIs on a yearly basis } \\
\text { Having KPI professionals and } \\
\text { specialists }\end{array}$ & $10 \%$ & $6 \%$ & $54 \%$ & $26 \%$ \\
\hline $\begin{array}{l}\text { Having change programs with KPI } \\
\text { implementation }\end{array}$ & $27 \%$ & $46 \%$ & $12 \%$ & $11 \%$ \\
\hline $\begin{array}{l}\text { Having technology to support KPI } \\
\text { implementation }\end{array}$ & $44 \%$ & $25 \%$ & $33 \%$ & $28 \%$ \\
\hline
\end{tabular}




\begin{tabular}{llccc}
\hline $\begin{array}{l}\text { Having a clear KPI implementation } \\
\text { internal communication plan }\end{array}$ & $47 \%$ & $13 \%$ & $32 \%$ & $8 \%$ \\
\hline $\begin{array}{l}\text { Having enough training and awareness } \\
\text { sessions before implementation }\end{array}$ & $55 \%$ & $29 \%$ & $10 \%$ & $6 \%$ \\
\hline
\end{tabular}

Table 10. How important are the following factors to your organization?

\begin{tabular}{|c|c|c|c|c|}
\hline & $\begin{array}{l}\text { Not } \\
\text { Important (1) }\end{array}$ & $\begin{array}{l}\text { Slightly } \\
\text { Important (2) }\end{array}$ & $\begin{array}{l}\text { Important } \\
\text { (3) }\end{array}$ & $\begin{array}{l}\text { Very } \\
\text { Important (4) }\end{array}$ \\
\hline Motivate the team to achieve the KPIs & $4 \%$ & $8 \%$ & $42 \%$ & $46 \%$ \\
\hline $\begin{array}{l}\text { Having buy-in from employees toward the } \\
\text { selected KPIs }\end{array}$ & $11 \%$ & $17 \%$ & $22 \%$ & $50 \%$ \\
\hline $\begin{array}{l}\text { Employee participation in the KPI } \\
\text { development necessary for buy-in }\end{array}$ & $15 \%$ & $21 \%$ & $31 \%$ & $33 \%$ \\
\hline Sharing one team's KPIs with other teams & $28 \%$ & $13 \%$ & $37 \%$ & $22 \%$ \\
\hline $\begin{array}{l}\text { Assigning specific employees to communicate } \\
\text { KPIs to the organization }\end{array}$ & $14 \%$ & $7 \%$ & $28 \%$ & $51 \%$ \\
\hline $\begin{array}{l}\text { Making better decision regarding employees } \\
\text { training based on KPIs results }\end{array}$ & $9 \%$ & $11 \%$ & $40 \%$ & $40 \%$ \\
\hline $\begin{array}{l}\text { Linking the promotion and bonus systems } \\
\text { with the KPIs results }\end{array}$ & $3 \%$ & $14 \%$ & $19 \%$ & $64 \%$ \\
\hline
\end{tabular}

Table 11. How would you rate your organization's actual performance on the following factors?

\begin{tabular}{lllll}
\hline & $\begin{array}{l}\text { Unsatisfactory } \\
(1)\end{array}$ & $\begin{array}{l}\text { Improvement } \\
\text { Needed (2) }\end{array}$ & $\begin{array}{l}\text { Meets } \\
\text { Expectations (3) }\end{array}$ & $\begin{array}{l}\text { Exceeds } \\
\text { Expectations (4) }\end{array}$ \\
\hline Motivate the team to achieve the KPIs & $27 \%$ & $42 \%$ & $27 \%$ & $4 \%$ \\
\hline $\begin{array}{l}\text { Having buy-in from employees toward } \\
\text { the selected KPIs }\end{array}$ & $30 \%$ & $39 \%$ & $18 \%$ & $12 \%$ \\
\hline $\begin{array}{l}\text { Employee participation in the KPI } \\
\text { development necessary for buy-in }\end{array}$ & $45 \%$ & $21 \%$ & $26 \%$ & $8 \%$ \\
\hline $\begin{array}{l}\text { Sharing one team's KPIs with other teams } \\
\text { Assigning specific employees to }\end{array}$ & $23 \%$ & $49 \%$ & $6 \%$ & $10 \%$ \\
\hline $\begin{array}{l}\text { communicate KPIs to the organization } \\
\text { employees training based on KPIs results }\end{array}$ & $33 \%$ & $24 \%$ & $20 \%$ \\
\hline $\begin{array}{l}\text { Linking the promotion and bonus systems } \\
\text { with the KPIs results }\end{array}$ & $40 \%$ & $19 \%$ & $30 \%$ & $17 \%$ \\
\hline
\end{tabular}

\subsection{Causes of KPI Implementations Challenges}

Lack of trust in the system and its benefits on a personal level was the reason most cited by the respondents for resisting KPI implementation. Other sources of employee resistance to KPI implementation included fear of change and extra job responsibilities, fear of being exposed, and reduced freedom of action. Interestingly, despite selecting the right KPI being identified as one of the major challenges to the implementation of KPIs, only 35 percent of the respondents felt that it was very important to have a well-designed KPIs selection process as shown in Table 8.

Having identified lack of KPI specialists as one of the challenges to the implementation of KPIs, many of the respondents (92 percent) felt that it was either 'important' or 'very important' to have KPI professionals and specialists in the organization. 78 percent of the respondents felt that it was 'important' or 'very important' to have a 
clear internal communication plan for KPI implementation and that sufficient training and awareness sessions should be held before implementation of the KPIs.

Judging from the responses in Table 9, it is clear that many of the respondents link the poor implementation of KPIs in their organization to leadership and strategic issues. For instance, as seen in the table, a majority of the respondents felt that the clarity of the goals and objectives of KPIs did not meet their expectations. The majority of the respondents also felt that the designs of KPIs selection processes in their organizations did not meet expectations. An even larger majority felt that the testing of KPIs before approval did not meet their expectations. From these responses, it is evident that a change in leadership and organizational strategy to focus more on, and hand greater importance to, the implementation of KPIs can help in mitigating many of the challenges experienced by businesses in the MENA region in implementing KPIs and enhance their efficiency in corporate performance.

A look at the research data shows that there is a wide gap between knowledge about the importance of KPIs best practices and the actual implementation of these best practices in the organization. For instance, as evident in Tables 8 and 9, while 90 percent of the respondents (important [10\%], very important [80\%]) reported that having clear KPI goals and objectives was afforded importance by their organization, only 44 percent of the respondents (meets expectations [21\%], exceeds expectations [23\%]) felt that the actual performance of their organizations in terms of having clear KPI goals and objectives met expectations.

Similarly, while 88 percent of respondents (important [42\%], very important [46\%]) stated that their organizations considered the motivation of employees to achieve KPI as important, only 31 percent of the respondents (meets expectations [27\%], exceeds expectations [4\%]) felt that their organizations actually motivated their employees to achieve the KPIs. This trend is repeated across all the factors evaluated in Tables 10 and 11.

This demonstrates the obvious gap between knowledge about many of the KPI best practices, on one hand, and the actual implementation of these best practices in the organization, on the other. These findings agree with previous research findings by Parmenter (2015) who established that despite being aware about the best practices in the selection and implementation of KPIs, many businesses usually develop a KPI system without following these practices.

The responses by the respondents also provide backing to hypothesis 2 that there is a significant relationship between having KPI professionals and specialists and effective implementation of KPIs. From the collected data in this research, it can be seen in table.... that 92 percent of the respondents (important [66\%], very important [26\%]) felt that it was important for an organization to have KPI professionals and specialists. However, only 38 percent of the respondents (meets expectations [12], exceeds expectations [26]) reported that they were confident that their organizations met expectations in terms of having qualified KPI professionals and specialists.

This research studied managers and directors, who are the people that would be expected to lead and supervise changes in the implementation of KPI in organizations. The fact that they have not implemented these changes so far implies that there might be some factors beyond their control that hinders their ability to implement desired change. This brings us to our third hypothesis, which is: There is a significant relationship between having clear KPI goals and objectives, on one hand, and the effective implementation of KPIs on the other. No matter how determined leaders are to implement KPIs, if the goals and objectives of the KPIs are not clear from the very start, then the implementation is unlikely to be successful.

The findings from this study do not directly agree or support this hypothesis and, as a result, the hypotheses are tested in the next section.

\subsection{Hypotheses Testing}

Table 12. Bivariate correlation analysis

\begin{tabular}{|c|c|c|}
\hline & $\begin{array}{l}\text { Having clear KPI Having } \\
\text { goals \& objectives professionals } \\
\text { specialists }\end{array}$ & $\begin{array}{l}\text { KPI Having enough training and } \\
\text { \& awareness sessions before } \\
\text { implementation }\end{array}$ \\
\hline 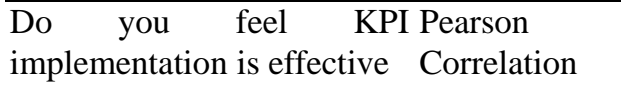 & .84 & .46 \\
\hline Sig. (2-tailed) & .0425 & .0647 \\
\hline $\mathrm{N}$ & 1007 & 1007 \\
\hline
\end{tabular}

*Correlation is significant at the 0.05 level (2-tailed) 
The bivariate correlation analysis of the variables associated with the three hypotheses returned the results shown in Table 12. Two of the correlations returned Sig. (2-tailed) values of less than 0.05 while the third returned a value just above 0.05 . What this means is that the correlation between having clear KPI goals and objectives, on one hand, and effective implementation of KPIs, on the other, as well as having KPI professionals and specialists, on one hand, and effective KPI implementation on the other, are significant. These prove hypotheses 2 and 3 . Hypotheses 1 , however, has not been proven as a value above 0.05 for a Sig. (2-tailed) bivariate correlation means that the correlation is not statistically significant (Aljandali, 2017). A further attempt to prove hypothesis 1 was made using the One-Sample Kolmogorov-Smirnov test.

The One-Sample Kolmogorov-Smirnov Tests in Table 13 also return values less than 0.05 for Asymptotic Significance (2-tailed), which means there was statistical significance and also implied that the tested variables do not follow either of the distributions (uniform, normal, poisson, and exponential) thereby making the null hypotheses not true (Heiberger \& Holland, 2015). Therefore, the tests of hypothesis one returned inconclusive results but the study proved hypotheses 2 and 3 to be true.

Table 13. One-Sample kolmogorov-smirnov test

Table: One-Sample Kolmogorov-Smirnov Test

\begin{tabular}{llllllllll}
\hline & & $v 9$. & $v 10$. & v11. & v12. & v13. & v14. & v15. & v16. \\
\hline $\mathrm{N}$ & & 1007 & 1007 & 1007 & 1007 & 1007 & 1007 & 1007 & 1007 \\
\hline Normal Parameters & Mean & 2.77 & 2.64 & 2.62 & 2.69 & 2.88 & 2.34 & 2.92 & 2.74 \\
\hline \multirow{2}{*}{ Most Extreme Differences } & Absolute & 0.33 & 0.37 & 0.37 & 0.28 & 0.35 & 0.28 & 0.41 & 0.35 \\
\hline \multirow{2}{*}{ Std. Deviation } & 0.81 & 0.72 & 0.72 & 0.83 & 0.81 & 0.67 & 0.74 & 0.78 \\
\hline & Positive & 0.26 & 0.28 & 0.27 & 0.23 & 0.28 & 0.28 & 0.33 & 0.27 \\
\hline Kolmogorov-Smirnov Z & Negative & -0.33 & -0.37 & -0.37 & -0.28 & -0.35 & -0.27 & -0.41 & -0.35 \\
\hline Asymp. Sig. (2-tailed) & & 6.17 & 7.04 & 6.86 & 5.24 & 6.55 & 5.25 & 7.69 & 6.53 \\
\hline
\end{tabular}

Table: One-Sample Kolmogorov-Smirnov Test

\begin{tabular}{llllllllll}
\hline & & $v 9$. & $v 10$. & v11. & v12. & v13. & v14. & v15. & v16. \\
\hline $\mathrm{N}$ & & 1007 & 1007 & 1007 & 1007 & 1007 & 1007 & 1007 & 1007 \\
\hline Uniform Parameters & Minimum & 0 & 0 & 0 & 0 & 0 & 0 & 0 & 0 \\
\hline & Maximum & 4 & 4 & 4 & 4 & 4 & 3 & 4 & 4 \\
\hline Most Extreme Differences & Absolute & 0.47 & 0.46 & 0.46 & 0.46 & 0.54 & 0.63 & 0.62 & 0.47 \\
\hline & Positive & 0.12 & 0.22 & 0.22 & 0.12 & 0.09 & 0.04 & 0.12 & 0.15 \\
\hline Kolmogorov-Smirnov Z & Negative & -0.47 & -0.46 & -0.46 & -0.46 & -0.54 & -0.63 & -0.62 & -0.47 \\
\hline Asymp. Sig. (2-tailed) & & 8.77 & 8.7 & 8.7 & 8.7 & 10.1 & 11.83 & 11.59 & 8.77 \\
\hline
\end{tabular}

Table: One-Sample Kolmogorov-Smirnov Test

\begin{tabular}{|c|c|c|c|c|c|c|c|c|c|}
\hline & & v9. & v10. & v11. & v12. & v13. & v14 & v15. & v16. \\
\hline $\mathrm{N}$ & & 1007 & 1007 & 1007 & 1007 & 1007 & 1007 & 1007 & 1007 \\
\hline Poisson Parameters & Lambda & 2.77 & 2.64 & 2.62 & 2.69 & 2.88 & 2.34 & 2.92 & 2.74 \\
\hline Most Extreme Differences & Absolute & 0.44 & 0.47 & 0.48 & 0.46 & 0.46 & 0.55 & 0.53 & 0.45 \\
\hline
\end{tabular}




\begin{tabular}{llllllllll}
\hline & Positive & 0.17 & 0.24 & 0.24 & 0.16 & 0.16 & 0.21 & 0.21 & 0.2 \\
\hline & Negative & -0.44 & -0.47 & -0.48 & -0.46 & -0.46 & -0.55 & -0.53 & -0.45 \\
\hline Kolmogorov-Smirnov Z & & 8.26 & 8.86 & 8.94 & 8.65 & 8.69 & 10.29 & 9.99 & 8.4 \\
\hline Asymp. Sig. (2-tailed) & & 0 & 0 & 0 & 0 & 0 & 0 & 0 & 0 \\
\hline
\end{tabular}

Table: One-Sample Kolmogorov-Smirnov Test

\begin{tabular}{llllllllll}
\hline & & v9. & v10. & v11. & v12. & v13. & v14. & v15. & v16. \\
\hline $\mathrm{N}$ & & 1007 & 1007 & 1007 & 1007 & 1007 & 1007 & 1007 & 1007 \\
\hline Exponential Parameters & Scale & 2.77 & 2.64 & 2.62 & 2.69 & 2.88 & 2.34 & 2.92 & 2.74 \\
\hline
\end{tabular}

\begin{tabular}{llllllllll}
\hline Most Extreme Differences & Absolute & 0.96 & 0.96 & 0.96 & 0.96 & 0.96 & 0.95 & 0.96 & 0.96 \\
\hline & Positive & 0.04 & 0.04 & 0.04 & 0.04 & 0.04 & 0.04 & 0.04 & 0.04 \\
\hline & Negative & -0.96 & -0.96 & -0.96 & -0.96 & -0.96 & -0.95 & -0.96 & -0.96 \\
\hline Kolmogorov-Smirnov Z & & 18.02 & 18 & 18 & 18.01 & 18.04 & 17.92 & 18.04 & 18.02 \\
\hline Asymp. Sig. (2-tailed) & & 0 & 0 & 0 & 0 & 0 & 0 & 0 & 0
\end{tabular}

\subsection{Reliability Test}

The reliability of the research instrument was tested during the pilot study. The Cronbach Alpha test was run on 8 items in the research instrument. The data for the test was obtained from 16 respondents drawn randomly from organizations within the Kingdom of Saudi Arabia. The choice of 16 respondents for the pilot study was made based on recommendations by Sarker et al. (2017) that a pilot sample size of between 16 and 36 respondents can produce results to a confidence level of 95 percent. The results for the Cronbach's Alpha Test are shown in Table 14 below.

Table 14. Cronbach's Alpha test

\begin{tabular}{ll}
\hline Cronbach's Alpha & No. of Items \\
\hline 0.97 & 8 \\
\hline
\end{tabular}

A Cronbach Alpha value of 0.7 or above implies that there is high internal consistency in the research instrument being tested (Park et al., 2015). Thus, the questionnaire used in this research had a high level of internal consistency and can be considered as reliable. Additionally, three of the 14 respondents involved in the pilot study were experts in the research subject and their expertise was utilized to evaluate the relevance of the questionnaire to the concepts and issues being studied. The input of these experts enhanced the validity of the study. The reliability of the survey research was also enhanced by the use of a standardized questionnaire (Ololube, 2015).

\section{Discussion}

This study sought to prove three hypotheses: (i) there is a significant relationship between having enough training and awareness sessions before implementation and effective implementation of KPIs; (ii) there is a significant relationship between having KPI professionals and specialists and effective implementation of KPIs; and (iii) there is a significant relationship between having clear KPI goals and objectives, on one hand, and the effective implementation of KPIs on the other. Hypotheses 2 and 3 were proved to be true while results for hypothesis 1 were inconclusive.

The findings in this study imply that encountering challenges in KPIs implementation is a common problem for most organizations in the MENA region. The implication of this finding is that businesses in the MENA region need to adopt new strategic thinking if they are to overcome the KPIS implementation challenges. Some of the modernistic strategies recommended as solutions to the common KPI implementation challenges include: Hiring KPI specialists to oversee the process of implementing KPIs; setting clear KPI goals and objectives; and combining the traditional business KPIs with modern data-sets, such as customer relationship management or employee performance 
management databases.

The findings indicate that most managers in the MENA region recognize the common challenges to the implementation of KPIs and many are actually working towards mitigating these challenges. There is growing recognition among many of the organizations in the region that the implementation of KPIs needs to be afforded equal importance and be approached like any other department in the organization.

This modernistic way of thinking has been proven as effective, both by this study and by previous studies, as a way of mitigating many of the challenges encountered in the implementation of KPIs by businesses in the Middle East and North Africa region. This new strategic thinking enhances the efficiency of businesses in corporate performance management.

\section{Conclusion and Recommendations}

This study investigated the new strategic thinking in mitigating the challenges in implementing key performance indicators (KPIs) and increasing efficiency in corporate performance management in MENA region. The study has established that many organizations tend to commit the following mistakes when implementing KPIs: lack of KPI specialists or professionals; lack of clear KPI goals and objectives; and relying on poorly designed KPI selection systems or processes. These shortcomings tend to make it difficult to choose the right KPIs thereby making their implementation more challenging. The study also established that some organizations have been stuck in the traditional or old ways of implementing KPIs despite the immense advances in technology.

Drawings from these findings and conclusions made in this study, the following recommendations are made:

- Organizations should departmentalize KPIs by having KPI specialists within the workforce and integrating the implementation of KPIs.

- Organizations should combine traditional business KPIs with modern data sets, such as employee performance management and customer relationship databases.

- Organizations have to adapt modern ways of storing and securing data.

- Organizations should review KPIs regularly and at the very least on a quarterly basis.

- Organizations should set clear KPI goals and objectives before the selection and implementation process commences.

\section{Further Research}

The subject of KPI implementation by organizations in the MENA region remains underexplored despite the adverse effects that poor implementation of KPIs can have on businesses. Consequently, more research needs to be conducted on this subject and with the dynamics of the MENA business environment in mind. Among the areas that can be investigated further include the impact of advances in technology on KPI implementation, the impact of national and regional regulations on KPI implementation in the MENA region, and the role of employees in easing the KPI implementation process. All these issues have been mentioned to varying degrees in this study and past studies as some of the factors that affect the implementation of key performance indicators. It is, therefore, important that they be investigated further.

Finally, the tests for hypothesis 1 in this study were inconclusive. Therefore, further research should be conducted to establish whether there is a significant relationship between having enough training and awareness sessions before implementation and effective implementation of KPIs.

\section{Limitations}

This research was limited by the fact that it was self-administered via an online questionnaire. Self-administration limits the reliability and validity of a research in various ways, including the likelihood that respondents might skip some of the questions in the questionnaire or fail to properly understand some of the questions in the questionnaire (Maxfield, 2015). Combining self-administered questionnaires with other data collection techniques, such as interviews, in future can allow the research to draw on the strengths of each thereby increasing the reliability of the research results.

\section{References}

Akkermans, H., Oppen, W., Wynstra, F., \& Voss, C. (2019). Contracting outsourced services with collaborative key performance indicators. Journal of Operations Management, 65(1), 22-47. https://doi.org/10.1002/joom.1002

Aljandali, A. (2017). Multivariate methods and forecasting with IBM SPSS statistics. New York: Springer. 
https://doi.org/10.1007/978-3-319-56481-4

Brockopp, D. Y., Hill, K. S., Bugajski, A. A., \& Lengerich, A. J. (2018). Establishing a research-friendly environment. Jones \& Bartlett Learning.

Cetinkaya, B., Cuthbertson, R., Ewer, G., Klaas-Wissing, T., Piotrowicz, W., \& Tyssen, C. (2011). Sustainable supply chain management: Practical ideas for moving towards best practice. Springer Science \& Business Media. https://doi.org/10.1007/978-3-642-12023-7

Coronel, C., \& Morris, S. (2018). Database systems: Design, implementation, \& management. Boston, MA: Cengage Learning.

Heiberger, R. M., \& Holland, B. (2015). Statistical analysis and data display: An intermediate course with examples in $R$. New York: Springer. https://doi.org/10.1007/978-1-4939-2122-5

Heppner, P. P., Wampold, B. E., Owen, J., \& Thompson, K. T. W. (2015). Research design in counseling. Cengage Learning.

Khanzadi, M., Sheikhkhoshkar, M., \& Banihashemi, S. (2018). BIM applications toward key performance indicators of construction projects in Iran. International Journal of Construction Management. https://doi.org/10.1080/15623599.2018.1484852

Latino, M. A., Latino, R. J., \& Latino, K. (2016). Root cause analysis: Improving performance for bottom-line results (4th ed.). Boca Raton: CRC Press. https://doi.org/10.1201/b10988

Leon, R. D. (2017). Managerial strategies for business sustainability during turbulent times. Hershey, PA: IGI Global. https://doi.org/10.4018/978-1-5225-2716-9

Marr, B. (2015). Key performance indicators for dummies. John Wiley \& Sons.

Maxfield, M. G. (2015). Basics of research methods for criminal justice and criminology. Cengage Learning.

Olawuyi, D. S. (2017). Local content requirements in oil and gas contracts: regional trends in the Middle East and North Africa. Journal of Energy \& Natural Resources Law, 37(1), 93-117. https://doi.org/10.1080/02646811.2018.1477494

Ololube, N. P. (2015). Handbook of research on enhancing teacher education with advanced instructional technologies. IGI Global. https://doi.org/10.4018/978-1-4666-8162-0

Park, J. J., Pan, Y., Kim, C., \& Yang, Y. (2015). Future information technology - II. New York: Springer. https://doi.org/10.1007/978-94-017-9558-6

Parmenter, D. (2015). Key performance indicators: Developing, implementing, and using winning KPIs. Hoboken, NJ: John Wiley \& Sons. https://doi.org/10.1002/9781119019855

Rastock, P. (2017). ITIL intermediate release, control and validation courseware. Hertogenbosch: Van Haren.

Sabri, E. (2019). Technology optimization and change management for successful digital supply chains. IGI Global. https://doi.org/10.4018/978-1-5225-7700-3

Sarker, R., Abbass, H. A., Dunstall, S., Kilby, P., Davis, R., \& Young, L. (2017). Data and decision sciences in action: Proceedings of the Australian society of operations research conference 2016. Springer. https://doi.org/10.1007/978-3-319-55914-8

Shohet, I. M., \& Nobili, L. (2016). Enterprise resource planning system for performance-based-maintenance of clinics. Automation in Construction, 65, 33-41. https://doi.org/10.1016/j.autcon.2016.01.008

Stricker, N., Minguillon, F. E., \& Lanza, G. (2017). Selecting key performance indicators for production with a linear programming approach. International Journal of Production Research, 55(19), 5537-5549. https://doi.org/10.1080/00207543.2017.1287444 